\title{
On Recent Developments in the New Historiography of (Neo)Liberalism
}

\author{
Iain Stewart
}

Helena Rosenblatt, The Lost History of Liberalism from Ancient Rome to the Twenty-First Century (Princeton NJ.: Princeton University Press, 2018), 348 pp. (hb), \$35, ISBN 978-0- 691-17070-1.

Dotan Leshem, The Origins of Neoliberalism: Modelling the Economy from Jesus to Foucault

(New York: Columbia University Press, 2017), 230 pp. (pb), £21, ISBN 978-023117777- 1 .

Marcel Gauchet, L'avénement de la démocratie, tome IV: Le nouveau monde (Paris: Gallimard, 2017), 749 pp (pb), 25€, ISBN 978-2070-78625-1.

Cornel Ban, Ruling Ideas: How Global Neoliberalism Goes Local (Oxford: Oxford University Press, 2016), 301 pp. (hb), £82, ISBN 978-0-19-060038-9.

Melinda Cooper, Family Values: Between Neoliberalism and the New Social Conservatism

(New York: Zone Books, 2017), 447 pp. (hb), £24, ISBN 978-1935-4089-40.

Quinn Slobodian, Globalists: The End of Empire and the Birth of Neoliberalism (Cambridge MA.: Harvard University Press, 2018), 381 pp. (hb), \$35, ISBN 9780-674-97952-9.

Over the last twenty years or so several new waves of research on the history of liberalism have emerged. The novelty of this should not be exaggerated as broad scholarly interest in liberalism has in fact been increasing at a remarkable rate since the 1980s.1 Nevertheless, it is

History Department, University College London, Gower Street, London, WC1E 6BT; i.stewart@ucl.ac.uk

1 The catalogue of the British Library is not totally comprehensive but is sufficiently representative to indicate the general trend towards an expansion of publications on liberalism. It lists 216 items with the word liberalism in their title or subject matter, including in languages other than English, published during the 1970s. In the 1980s the equivalent figure is 574. This rises to 999 in the 1990s and to 1314 in the 2000s. As of late March 2019 the figure for the $2010 \mathrm{~s}$ is 1,059 . This indicates a decline on the previous decade, although this is compensated by a large increase in publications on neoliberalism in this decade. An equivalent search for 'neoliberalism' and 'neo-liberalism' returns no results for the 1970s, 
clear that the historiography of liberalism has broken much new ground since around the turn of the century. This has been driven partly by the influence of larger developments in the humanities and social sciences. The global and post-colonial turns, for instance, have helped to reshape the historiography of liberalism by provoking debates over the extent of its complicity in slavery and colonialism, while also drawing attention to the contribution of theorists from the global south.2 But even much of this 'normal' innovation has been driven at least indirectly by a growing sense that liberalism is in crisis. The War on Terror, the financial meltdown of 2008 and the global rise of populist authoritarianism are the obvious staging posts in liberalism's journey from post-Cold War triumphalism to contemporary fears for its imminent demise. And it is not a coincidence that the end of the end of history has seen the beginning of a new historiography of liberalism. Since the early 2000s the emergence of new sub-fields like the histories of 'Cold War liberalism', human rights and neoliberalism can all be seen in different ways as responding to liberalism's unfolding crisis.

The last time the recent historiography of liberalism was surveyed in this journal, Emile Chabal remarked upon the generally sympathetic stance adopted by the works under review.3 Yet much of the new historiography of liberalism has been at least implicitly oppositional. This is most obviously the case in the historiographies of neoliberalism and, to a somewhat lesser degree, human rights. Even sympathetic treatments of historical liberalism have often evinced a therapeutic tendency predicated on a recognition of contemporary liberalism's inadequacies. From this standpoint, to write the history of liberalism is not to eight for the 1980s (of which six are in Spanish), forty-five for the 1990s, 303 for the 2000s and 870 for the 2010s.

2 Among the many important works on these themes see, for example, Barbara Arneil, John Locke and America: The Defence of English Colonialism (Oxford: Oxford University Press, 1996); Uday Singh Mehta, Liberalism and Empire: A Study in Nineteenth-Century British Liberal Thought (Chicago: Chicago University Press, 1999); Jennifer Pitts, A Turn to Empire: The Rise of Imperial Liberalism in Britain and France (Princeton NJ.: Princeton University Press, 2005); C. A. Bayly, Recovering Liberties: Indian Political Thought in the Age of Liberalism and Empire (Cambridge: Cambridge University Press, 2012); Andrew Sartori, Liberalism in Empire: An Alternative History (Oakland CA.: University of California Press, 2014).

3 Emile Chabal, 'The Agonies of Liberalism', Contemporary European History, 25, 4 (2016), $162-3$. 
trace the origins of our contemporary crisis; rather, it is to consider whether there might be resources within the liberal tradition that might contribute to its renewal. The history of Cold War liberalism is one area where this therapeutic tendency is becoming apparent.4 Likewise, the election of Donald Trump has led some historians and political scientists to argue for a rediscovery of mid-twentieth-century anti-totalitarian thought as a resource for confronting the populist threat to liberal democracy.5

\section{Helena Rosenblatt's The Lost History of Liberalism from Ancient Rome to the} Twenty-First Century fits squarely into this therapeutic reading of liberalism. The book sets out to disprove 'the idea that liberalism is an Anglo-American tradition concerned primarily with the protection of individual rights and interests'.6 Rosenblatt makes this case well and in doing so offers one of the best available general histories of liberalism in the long nineteenth century. This in itself is clearly an impressive and timely achievement. But the book's most ambitious claims regarding the notion of a 'lost history' are unconvincing because they rest on a limited discussion of twentieth-century liberalism while exaggerating the originality of Rosenblatt's more substantive and persuasive account of the nineteenth century.

4 See most recently Jan-Werner Müller, 'What Cold War Liberalism can Teach us Today', The New York Times Review of Books: NYR Daily, 26 November, 2018: https://www.nybooks.com/daily/2018/11/26/what-cold-war-liberalism-can-teach-us-today/ [accessed 26 Feb. 2019]. For a contrasting take on this subject see Samuel Moyn, 'Before and Beyond - The Liberalism of Fear', in Samantha Ashenden and Andreas Hess, eds., Between Utopianism and Realism: The Political Thought of Judith Shklar (Philadelphia: Pennsylvania University Press, 2019).

5 Timothy Snyder, On Tyranny: Twenty Lessons for the Twenty-First Century (London: The Bodley Head, 2017); Jan Zielonka, 'Liberal Europe Must Retrieve its Moral Compass', Prospect, 2 February 2018. https://www.prospectmagazine.co.uk/politics/liberal-europemust-retrieve-its-moral-compass [accessed 26 February 2019]. For a critique of the influence of Cold War liberalism in the recent literature on the contemporary crisis of democracy see Jedediah Purdy, 'Normcore', Dissent (Summer 2018): https://www.dissentmagazine.org/article/normcore-trump-resistance-books-crisis-ofdemocracy [accessed 4 April 2019].

6 Helena Rosenblatt, The Lost History of Liberalism from Ancient Rome to the Twenty-First Century (Princeton NJ.: Princeton University Press, 2018), 4. 
What has been lost from the history of liberalism? According to Rosenblatt the missing elements are liberalism's 'republican beginnings', its continental European origins and its ties to Christianity.7 These issues have hardly been 'lost' in the recent historiography of liberalism, 8 but it is true that narrowly individualistic and Anglo-American understandings of liberalism understate their importance. Focusing on them allows the book to make two larger claims about the history of liberalism in the long nineteenth century. The first concerns historical narrative: 'the truth is that France invented liberalism in the early years of the nineteenth century and Germany reconfigured it half a century later. America took possession of liberalism only in the early twentieth century.' 9 While attentive to national specificity, the book does not compartmentalise national traditions. Rosenblatt is equally enlightening, for instance, on how 'liberalism' acquired its specifically progressive connotations in the United States and on how debates over religion and education crossed national borders in the late nineteenth century. A second of the book's main claims is that in the long nineteenth century liberals tended to be moralists more concerned with the public good than with individual rights and that by the end of the century liberalism had begun to incorporate elements of socialism and feminism. Neither of these larger arguments about nineteenth-century liberalism is new, but Rosenblatt is surely right to intuit that they are worth restating in the context of liberalism's current moment of crisis.

On the methodological front, the book's claim to originality is more persuasive. In her introduction, Rosenblatt pointedly refuses to offer a definition of liberalism around which to build her history; instead, she offers 'a word history of liberalism' focused on how the meanings ascribed to the words 'liberal' and 'liberalism' have changed over time and space.10

7 Rosenblatt, Lost History, 3-5, 9.

8 For liberalism and republicanism see e.g. Andreas Kalyvas and Ira Katznelson, Liberal Beginnings: Making a Republic for the Moderns (Cambridge: Cambridge University Press, 2008); for an emphasis on liberalism's European history see e.g. Edmund Fawcett, Liberalism: The Life of an Idea (Princeton NJ.: Princeton University Press, 2014); for liberalism and Christianity see e.g. Larry Siedentop, Inventing the Individual: The Origins of Western Liberalism (London: Penguin, 2014).

9 Rosenblatt, Lost History, 3.

10 Rosenblatt, Lost History, 3. This refusal to define liberalism is somewhat surprising in light of Rosenblatt's apparently contrary stance on this question as recently as 2017 . See Helena Rosenblatt, 'What is Liberalism?', Politics, Religion and Ideology, 18, 3, (2017), 331-3. 
This nominalist method avoids the danger of anachronism, but the argument that it serves is historically questionable in a different sense. By focussing on 'self-titled liberals' Rosenblatt sometimes gives the impression that the intellectual history of liberalism amounts to a competition among its adherents to define what 'true liberalism' really is. While this may be plausible in some instances, such as late nineteenth-century Anglophone debates around the 'new liberalism', it overlooks the fact that after 1848 continental political thinkers working within a liberal tradition were often reluctant explicitly to self-identify as liberals. Most of the intellectuals who contributed to the so-called 'French liberal revival' of the 1970s and 1980s, for instance, did not self-identify as liberals, despite the fundamental importance of authors like Constant, Guizot and Tocqueville for their project of rethinking the history and theory of democracy. In this instance Rosenblatt's focus on 'self-titled liberals' works to the detriment of her larger argument, since these French intellectuals did much to propagate the conflictual view of liberalism's relationship with republicanism that Rosenblatt begins her history by contesting.

The book's opening chapter, 'What it Meant to be Liberal from Cicero to Lafayette', is a missed opportunity in this regard. The argument here is that before the advent of 'liberalism' the political meaning of 'liberal' originated from 'republican beginnings'.11 As such, liberality understood politically denoted civic virtue, devotion to the common good and respect for mutual connectedness, qualities that continued to be understood as 'liberal' well into the nineteenth century. Rosenblatt makes this case quite convincingly but its implications for her most ambitious argument are left unexplored. To the extent that she is right about there being a 'lost history' of liberalism, part of the explanation for this can presumably be found in the influence of scholars like Quentin Skinner, Philip Pettit, François Furet and Pierre Rosanvallon, who in different ways and for different reasons disimbricated liberalism from republicanism in their work between the 1970s and the 1990s. Framing the book's account of liberalism's republican beginnings critically in relation to such scholarship might have made the titular link 'from ancient Rome to the twenty-first century' more meaningful, but the potentially crucial question of liberalism's relationship with republicanism is more or less dropped after the first chapter.

How the cliché of liberalism as an Anglophone and a narrowly individualistic tradition gained traction in the twentieth century is a good question. Rosenblatt's answer is 
broadly in agreement with recent work on this theme by Duncan Bell and Samuel Moyn.12 Like Bell, she sees the Anglo-American version of the liberal tradition as a product of the Cold War, and, like Moyn, she argues that the anti-totalitarian reinvention of liberalism entailed a narrowing of normative horizons. From the mid-twentieth century, she writes, liberals 'lowered their sights and adjusted their goals'.13 As liberalism was turned into a primarily negative doctrine aimed at the protection of basic individual rights it 'conceded the high ground to its adversaries'.14 There is more than a grain of truth in this argument, but it is inevitably underdeveloped since it is only briefly sketched in the book's epilogue. One necessary point of qualification is that 'Cold War liberalism' was not only a 'liberalism of fear', it also helped to shape a socio-economic model that, for all its many limitations, was more equitable than any that came before or after it in the modern era. Nor can generalisations about atomistic individualism be applied to Cold War liberalism, given the strong personalist influence on its social philosophy. Finally, it is necessary to devote more attention to the complicated relationship between Cold War liberalism and the neoliberal revolution that began in the 1970s. Although the absence of neoliberalism is arguably the real lost history in Rosenblatt's book, her wide-ranging and authoritative treatment of the long nineteenth century invites us to think again about such important questions as liberalism's relationship with religion, family and gender, issues that are also central to some of the other works under review here.

Like The Lost History of Liberalism, Dotan Leshem's The Origins of Neoliberalism: Modelling the Economy from Jesus to Foucault is a word history. But, instead of liberalism, Leshem focuses on oikonomia, the original Greek word for economy. Leshem's argument is that this term took on a new meaning in the Christianity of Late Antiquity, which he identifies as 'the key moment in the genealogy of the neoliberal marketized economy'.15 For pre-Christian Greek philosophers, the purpose of economic activity was to meet the basic material needs of existence in a way that generated surplus leisure time for devotion to the higher activities of philosophy or politics. From its inception, then, the oikonomia was a

12 Duncan Bell, Reordering the World: Essays on Liberalism and Empire (Princeton NJ.: Princeton University Press 2016), 62-90; Moyn, 'Before - and Beyond - the Liberalism of Fear'.

13 Rosenblatt, Lost History, 268.

14 Rosenblatt, Lost History, 266.

15 Dotan Leshem, The Origins of Neoliberalism: Modelling the Economy from Jesus to Foucault (New York: Columbia University Press, 2017), 6. 
strongly gendered category that presupposed a specific relationship between the matron, identified as 'the first person in our Western history to live a one-dimensional economic life as a freeborn person', and the master, whose ability to pursue the higher callings of philosophy and politics depended on matronly economic competence.16 Such competence was defined by the achievement of subsistence and the avoidance of economic excess; crucially, the surplus created by virtuous economic management was extra-economic. Put very simply, what changed with the Christianity of Late Antiquity was that the purpose and scope of economic activity changed: as oikonomia came to designate God's divine plan, the management of economic affairs became a supreme end in itself; the idea of economic excess having previously been maligned, now for the first time it became possible to conceive of and valorise economic growth.

There are several possible objections to this argument. First, it could be argued that the extent of the semantic difference between ancient Greek and early Christian uses of the term oikonomia is so great that the object to which the term refers is completely different, rendering comparison pointless. But a careful reading of the text shows that this is not the case. Leshem's erudition in reconstructing oikonomia's early semantic odyssey is extremely impressive. He acknowledges that the thing to which oikonomia refers changes profoundly between the classical and early Christian epochs, but he also exposes a remarkable degree of consistency in the way that oikonomia is defined in the abstract, even as its referent in the world seems to have changed almost beyond recognition. This arguably neutralises a second possible objection, which is that Leshem's account of oikonomia's semantic trajectory beyond Late Antiquity is rather cursory compared to his painstaking discussion of the crucial earlier period, and that consequently he does not do anywhere near enough historically to substantiate the claim that the seed of the neoliberal economy was planted by early Christian theologians. Since Leshem's intention is not conventionally historical but genealogical, however, this would be unfair. A final objection concerns the centrality of economic growth for Leshem's argument, and it is here that his account of The Origins of Neoliberalism is ultimately unconvincing. The problem with placing this notion at the centre of the argument is that while neoliberalism is certainly preoccupied with economic growth, this was hardly a distinctive trait: the same could be said of the 'embedded liberalism' that preceded it and, indeed, of Soviet communism. 
Like The Lost History of Liberalism, then, The Origins of Neoliberalism is a work of considerable erudition and insight that is oversold by its title. That its most ambitious argument is unconvincing does not detract from the importance of its scholarly contribution in other respects.17 Like Helena Rosenblatt and other authors whose books are reviewed here, Leshem reminds us of the importance of religion in the history of liberalism. The story that he tells is not one of secularisation but rather of 'a radicalization of the Christian theory of economic growth' such that 'the shift that occurred with the marketization of the Christian economy is not the expulsion of God from economy'.18

This contrasts markedly with the argument set out by Marcel Gauchet in Le nouveau monde, where the neoliberal revolution is presented as a symptom of Europe's 'exit from religion'.19 This is not a claim about the waning influence of religious institutions, nor is it an argument about declining patterns of religious belief and practices among individuals or groups; instead, Gauchet's 'exit from religion' concerns religion's symbolic function in the constitution of human societies. It refers to the final completion of a centuries-long process in which the symbolic function of 'the religious' was absorbed into 'the political'. For Gauchet, this process marks the gradual transition from a state of 'heteronomy', wherein the social world is understood to be governed by a supernatural agent, to a state of 'autonomy', wherein that world is understood to be a product of human design.20 Among the most important stages in the development of this process are the advent of Christianity, which Gauchet famously described as 'the religion of the exit from religion',21 the birth of the state, the French Revolution and the rise of totalitarian secular religions. It was only in the 1970s, with the simultaneous collapse of faith in communism and the crisis of the post-war Keynesian state that the last vestiges of religious influence were finally evacuated from politics, thereby

17 There is not space here to cover Leshem's fascinating and persuasive commentary on the works of Arendt, Agamben and Foucault, for instance, but anyone with an interest in these thinkers will benefit from reading this book.

18 Leshem, Origins of Neoliberalism, 168.

19 Marcel Gauchet, L'avénement de la démocratie, tome IV: Le nouveau monde (Paris: Gallimard, 2017),17-18.

20 For a more detailed overview of this argument see the review by Michael C. Behrent, 'Age of Emancipation', Dissent, (Winter 2018). https://www.dissentmagazine.org/article/age-ofemancipation-marcel-gauchet-democracy-review [accessed 26 February 2019]

21 Marcel Gauchet, Le désenchantement du monde: une histoire politique de la religion (Paris: Gallimard, 1985), ii. 
completing the 'final theologico-political turn of modernity'.22 For Gauchet, the neoliberal revolution manifests this 'exit from religion' at the level of the economy.

This reframing of the neoliberal moment within a comprehensive philosophy of history is both the great strength and weakness of Gauchet's book. The advantage of framing neoliberalism in this way is that it opens a kind of bi-focal perspective on the subject, one that is alternately panoramic and intimate. Panoramic in that it allows us to see neoliberalism as part of a larger cultural moment that gave rise to parallel and profoundly connected developments like the rise of individual rights or the discourse of post-modernity. Intimate in its attention to the effects of the exit from religion at the level of individual subjectivity, such that it could be read partly as a non-Foucauldian account of 'everyday neoliberalism'.23 One does not have to buy into the underlying philosophy of history to find this approach stimulating. Yet Gauchet's bifocal perspective is also strangely monocular in its primarily cultural orientation. Real world economic developments are not absent from his account, but they function mainly to expose transformations in the underlying symbolic economy. Ultimately the relationship between neoliberalism and the exit from religion is never very clearly articulated. This does not mean that the book is a failure. The neoliberal revolution is but one part of the story that Gauchet is trying to tell here; his articulation of the relationship between individual rights and 'the final theologico-political turn of modernity', for instance, is somewhat clearer and more compelling. But the book overall is more impressive as a philosophy of history than as a history of the economy.

Cornel Ban's Ruling Ideas is a very different kind of book, but its staunch empiricism does not prevent it from making a scholarly contribution that transcends the particular case studies on which it is based. Billed as a study of How Global Neoliberalism Goes Local, it offers a comparative account of how neoliberal ideas influenced policy in Spain and Romania during the years between democratic transition and the aftermath of the Eurozone crisis. In line with previous scholarship on localised neoliberalism, Ban argues that 'rather than a mass-produced, slightly shrunk and off-the-rack ideological suit, neoliberalism is a bespoke outfit made from a dynamic fabric that absorbs local colour'.24 But he also goes beyond this by offering a conceptual framework for understanding different varieties of localised

22 Gauchet, Le nouveau monde,145-200.

23 On 'everyday neoliberalism' see Philip Mirowski, Never Let a Serious Crisis go to Waste: How Neoliberalism Survived the Financial Meltdown (London: Verso, 2014), 89-156.

24 Cornel Ban, Ruling Ideas: How Global Neoliberalism Goes Local (Oxford: Oxford University Press, 2016), 5. 
neoliberalism and an explanatory model to account for such local variation. The conceptual framework applies the Polanyian metaphor of embeddedness to neoliberalism, which is defined as 'a set of economic ideas and associated policies that have a constant goal (to enlarge the realm of the market) and a variable one (to carry out upwards redistribution)'.25 Where national governments enact policies to mitigate against the social dislocation produced by neoliberalisation the resulting hybrid is understood as a form of 'embedded neoliberalism'; where policies are enacted with the aim of achieving an unrestricted expansion of markets and upwards redistribution of wealth then 'disembedded neoliberalism' results.26 The explanatory model emerges from Ban's empirical research, which includes published primary source material alongside an extensive list of interviews with officials from governments, central banks and international organisations.

Put simply, Ban's comparison shows that while Spain's socialist government implemented embedded neoliberalism immediately upon coming to power in 1982 and only moved towards disembedded neoliberalism under external duress during the Eurozone crisis, Romania rejected neoliberalism altogether until the late 1990s but then implemented increasingly radical neoliberal reforms such that by the time of the Eurozone crisis its government ignored advice from the IMF to moderate its reform agenda and pursue a more socially equitable policy path. Ban's explanation of Romania's journey from the neodevelopmentalism of the early 1990s to the neoliberal extremism of the 2000s is the book's least satisfying aspect. He lays the emphasis here on the relatively limited exposure of Romanian economists to neoliberal ideas, their relatively weak ties to the most prestigious economics departments in the United Kingdom and the United States, and, during the crisis and its aftermath, the influence of think tanks staffed by non-economists. One sometimes has the impression that correlation is standing in for causation in parts of this argument, and that, were more evidence readily available, then greater weight might well be granted to the problem of endemic corruption, which Ban duly notes without, quite understandably, being able to integrate it into his empirically grounded approach.

Ban's discussion of Spanish neoliberalisation is more compelling. Previous accounts have tended to explain Spanish socialists' embrace of neoliberalism as a response to the 
failure of the early economic policies of the Mitterrand government in France.27 Yet while this was used as a cautionary tale to bring party members into line, the party elite responsible for economic policy had converted to the cause of a moderated neoliberalism before Mitterrand's election in 1981. From a historical point of view, Ban's multi-layered explanation for this conversion is the most interesting thing about the book. He explains it in the first instance as resulting from the influence of neoliberal theories within the Research Institute of Spain's central bank, which was the main training ground for the experts who shaped socialist economic policy thinking in the 1980s. But he also traces the deep history of Iberian neoliberalism since the 1930s, when Spanish economists began importing new liberal economics after training in British and German universities. In the long run, the most important influence on the importation of neoliberal ideas to Spain was the German ordoliberal Heinrich Freiherr von Stackelberg, who joined the University of Madrid in 1943 and left a lasting mark on a group of economists who became increasingly influential in the 1970s. Finally, Ban discusses the considerable efforts of Germany's Social Democratic Party in the same decade to convert Spanish socialists to an economic policy programme based on a blend of ordoliberal and social democratic ideas, highlighting the role of socialist internationalism in facilitating the dissemination of neoliberal ideas.

Melinda Cooper's latest book examines the broad appeal of neoliberal ideas from a different perspective. In Family Values she explains how an alliance forged between neoliberal economists and new social conservatives in the United States during the inflationary decade of the 1970s helped to revolutionise the politics of welfare, public health and private debt over the following three decades. What is most original about the book is not so much its subject matter as the method by which it is approached. By placing the question of family at the centre of her analysis, Cooper forces us to rethink both the history of neoliberalism and the theories and methods with which we study it. Her book's contribution to the history of liberalism thus extends far beyond the late twentieth-century American context with which it is immediately concerned.

Family Values is grounded in a critique of Karl Polanyi's influential 'double movement' theory of capitalism's history as having developed through the combination of a socially disintegrative movement toward market expansion and a socially re-integrative

27 Here Ban cites Carles Boix, Political Parties, Growth and Equality: Conservative and Social Democratic Economic Strategies in the World Economy (Cambridge: Cambridge University Press, 1998), 108. 
counter-movement to constrain markets. Cooper's method is based firstly on a Marxist correction of Polanyi's theory of the double movement in which, unlike for Polanyi, both movement and counter-movement are seen as internal to capitalism, and, secondly, on a feminist reorientation of Marx towards questions of family, gender and race. This is what allows her to answer the question of why neoliberals and new social conservatives have been able to find common cause on the question of 'family values'. Viewed in this light, the advent of neoliberal capitalism entailed both a dis-integrative tendency in relation to the Fordist family unit and a compensatory revival of poor law traditions of family dependency in social policy. Put simply, neoliberals shared conservative concerns about family breakdown insofar as this contributed to expanding welfare costs, and they promoted the politics of 'family values' in an attempt to shift the economic burden of social policy onto families. Cooper shows this dynamic at work across a series of case studies on welfare reform, the political economy of inheritance, neoliberal responses to the AIDS crisis and the rise of student debt. Her larger argument is perhaps not sustained consistently well across all these chapters. For instance, the influence of the poor law tradition is demonstrated very effectively in the first of the chapters on welfare reform but less so subsequently, while the book sometimes loses sight of the informal coalitional politics between neoliberals and neoconservatives to which its subtitle refers. Nevertheless, every chapter is an outstanding work of scholarship in its own right, and Cooper's grasp of the intellectual, social, political and economic aspects of each topic is such that the overall effect comes close to a kind of total history of domestic American neoliberalism.

Family Values also has significant implications for historical scholarship on neoliberalism more broadly. In addition to its powerful critique of the Polanyian paradigm, two other points should be emphasised here. Firstly, historians have tended to take the 'neo' in neoliberalism seriously, and rightly so, but this book shows that as far as the family is concerned the gap between neoliberalism and nineteenth century liberalism is not so wide. Probably Cooper's most important general contribution is to have shown that throughout its history the notion of liberalism as an individualistic philosophy has overlooked the family politics that makes this individualism possible. A second larger contribution is to have offered a corrective to the now longstanding tendency to see neoliberal hegemony as resulting from its ability to appeal to the values of the New Left. One consequence of this is that the relationship between Cold War liberalism and the neoliberal revolution will have to be carefully re-examined in the wake of Cooper's work. 
Quinn Slobodian's book offers a fresh take on neoliberalism by considering it as a theory of how a world of nation states could be made to co-exist with a global market economy. The end of empire provides the essential backdrop for understanding this intellectual history. It was no coincidence that neoliberal globalism was born in 1920s Vienna, since nostalgia for the Habsburg empire was fundamental to the neoliberal dream of a multi-national single market world economy. But this was never imagined as a dream that could be realised simply by removing barriers to trade and allowing the spontaneous operation of market forces. Instead, Slobodian shows that the aim of neoliberal globalism was 'not to liberate markets but to encase them' by redesigning the political and legal structures necessary to create and sustain them. 28

In this respect, he presents neoliberal global thought as a scaled-up version of German ordoliberalism, an 'Ordoglobalism' as he puts it.29 This is useful shorthand, but potentially misleading from the standpoint of intellectual history, since notwithstanding the involvement of Germans such as Wilhelm Röpke, the origins of the theory that Slobodian reconstructs predate ordoliberalism. A similar issue arises from his frequent references to Carl Schmitt's distinction between imperium, the world of territorially bounded states, and dominion, the world of property, to describe a neoliberal global imaginary whose essential features long predated Schmitt's use of these terms. Slobodian's identification of a 'Geneva School of Neoliberalism', 30 to take a final example, is an effective conceptual device for grouping the various thinkers covered in the book, but while he successfully demonstrates the coherence of this school from an ideational standpoint, its status as an institutional reality is questionable.

These are relatively minor reservations, however, and the book overall makes a major contribution to the historiography of neoliberalism. Although there is an extensive literature on the international organisations through which neoliberal policies were globalised, this is the first comprehensive intellectual history of a neoliberal philosophy of global governance. Beginning in the 1920s with the earliest co-ordinated attempts to theorise the world economy, it finishes by examining the way that neoliberal jurists worked to beef up the General Agreement on Trades and Tariffs, prefiguring the establishment of its more powerful successor, the World Trade Organisation, in 1995. Along the way Slobodian offers insightful discussions of Ordoglobalism's epistemology and federalism, its conflicted views on early

28 Quinn Slobodian, Globalists: The End of Empire and the Birth of Neoliberalism (Cambridge MA.: Harvard University Press, 2018), 2.

29 Slobodian, Globalists, 12.

30 Slobodian, Globalists, 7-8. 
European integration and racial segregation, its initially unsuccessful but ultimately prescient efforts to co-opt the language of human rights in the service of global business interests and its relationship with cybernetics and systems theory. Although its discussion of the GATT and WTO takes the book from the 1980s into the mid-1990s, it is notable that Slobodian does not discuss contemporary developments in European integration. This may be because the prominent role of French socialists, most notably Jacques Delors, in this history make it a hard fit for the story that he is trying to tell, but it would nevertheless have been interesting to know how Ordoglobalists contributed to debates around the Single European Act and the Maastricht Treaty, a question of obvious relevance to the book's concern with Ordoglobalism's complicated relationship with democracy.

Writing the history of neoliberal globalism brings our attention to several less well known but still influential intellectuals, such as Gottfried Harberler and Michael Heilperin, while casting familiar figures like Ludwig von Mises and Friedrich von Hayek in a new light. As Slobodian rightly points out, in much of the scholarship on neoliberalism 'The name of Hayek, in particular, often operates as a free-floating signifier more than an index to an actual historical figure'.31 The Hayek that we encounter in Globalists is primarily a legal and political theorist for whom the economics of neoliberalism are less important than its epistemology, in which the economy is posited as fundamentally unknowable. This claim is the foundation on which mature neoliberal globalism was built, and much of the book is devoted to expositing the complex implications that neoliberals drew from it in the decades after the Second World War. In conclusion, Slobodian writes that it amounted to 'a negative theology, contending that the world economy is sublime and ineffable',32 before somewhat deflating this argument by remarking that what he had dignified as a negative theology was deliberately constructed to expose economic planning and redistribution as fundamentally illconceived. Here the larger question arises of the extent to which neoliberalism and the international networks through which it is promoted are simply the ideological agents of the business interests that they served. One of the great qualities of Globalists is that its exposure of the Ordoglobalists' ties to the world of international business is not an exposé. While the author regards neoliberalism as a project for the restoration of class power, he acknowledges that its theorists were true believers whose ambitions for reshaping the world economy far outstripped those of their funders.

31 Slobodian, Globalists, 5.

32 Slobodian, Globalists, 269. 
The new historiography of liberalism that emerged around the turn of the century was innovative in large part because it brought a series of new sub-fields into being. While most of the books under review here can be situated within these extant but still relatively new areas of research, they nevertheless offer multiple new insights into their topics, raise methodological questions of wider relevance and point towards potentially fruitful new avenues of research.

On the latter point it seems clear that the new historiography of liberalism has reached a stage where it might now be possible to write a general history of western liberalism in the twentieth century. 33 One of the questions that such a history would have to answer concerns the relationship between so-called Cold War liberalism of the mid-twentieth century and the neoliberal revolution of the late twentieth century. The authors under review here offer contrasting responses to this question. Rosenblatt implicitly de-emphasises the differences between these two versions of twentieth-century liberalism by suggesting that both contributed to a narrowing of horizons wherein liberalism came to be re-imagined as an individualistic and economistic doctrine far removed from most of its nineteenth-century iterations. One of Cooper's many important contributions is to have highlighted the previously under-acknowledged degree of overlap between neoliberal and neoconservative priorities in the realm of family politics in the United States. But Slobodian shows, on the other hand, that for European neoliberal intellectuals 'the Cold War was a sideshow to the main event of the rise of mass enfranchisement and the end of empire'.34

On the subject of neoliberalism, some of the works under review also offer a strong response to two of the more common criticisms levelled at this concept. One such criticism is that the idea of a neoliberal revolution is misleading because the size of the state has not shrunk as a result of neoliberal reforms. Yet as Ban, Slobodian and Cooper all show, it is a mistake to equate actually existing neoliberalism with anti-statist market fundamentalism. Although some neoliberal theorists may have proposed a rollback of the state, the aim of neoliberal policy reforms has generally not been to shrink but to repurpose the state, whether

33 On the relatively underdeveloped state of scholarship on the history of Asian neoliberalism see Chabal, 'The Agonies of Liberalism', 172.

34 Slobodian, Globalists, 264. 
as an enforcer of free markets or of family values. A second, more general objection to the idea of neoliberalism refers to the alleged vagueness of a concept that is used interchangeably to describe an economic theory, a set of policies, a political rationality, a form of capitalism and a lived reality.35 Ban and Slobodian remind us of neoliberalism's empirically verifiable existence as an intellectual project that cultivated identifiable ties to the worlds of business, finance and politics. And, as Ban and Cooper show, the fact that neoliberal ideas change as they make the journey from high theory to practical policy implementation hardly means that the concept of neoliberalism should be abandoned. Indeed, it is precisely the ability of neoliberalism to market itself to non-liberal political constituencies on the left and right that goes a long way towards explaining the breadth of its influence since the 1980s.

35 For an enlightening recent discussion of these issues see Dissent magazine's forum on Daniel Rodgers, "The Uses and Abuses of "Neoliberalism", Dissent (Winter 2018). https://www.dissentmagazine.org/article/uses-and-abuses-neoliberalism-debate [accessed 3 July 2019] 